\title{
Comparative study of the chemical composition, fatty acid profile, and nutritional quality of Lophiosilurus alexandri (Siluriformes: Pseudopimelodidae), a Brazilian carnivorous freshwater fish, grown in lotic, lentic, and aquaculture environments
}

\author{
Léa S. Sant'Ana ${ }^{1}$, Adriane A. Iwamoto ${ }^{1}$, Daniel V. Crepaldi², Túlio P. Boaventura ${ }^{3}$, \\ Lilian V. Teixeira ${ }^{3}$, Edgar A. Teixeira ${ }^{3}$ and Ronald K. Luz ${ }^{3}$
}

Lophiosilurus alexandri is a carnivorous freshwater fish endemic of São Francisco basin and an endangered species. In this study, we analysed the chemical composition (moisture, protein, ash and lipid), fatty acid profile, and nutritional quality (atherogenic index, thrombogenecity index, ratio between hypocholesterolemic and hypercholesterolemic fatty acids and $\omega 6 / \omega 3=$ ratio) of $L$. alexandri in lotic (river), lentic (hydroelectric dams) environments, under natural fed, and in laboratory controlled conditions fed with commercial diets. Cultured and lentic fish had significantly higher lipid levels (1.5 and 1.9- fold, respectively) than lotic fish. Lentic L. alexandri had significantly higher eicosapentaenoic acid (EPA) levels (4×) than cultured or lotic L. alexandri. Docosahexaenoic acid (DHA) levels were the highest in lentic fish, followed by lotic fish. Lentic fish had greater proportion of fatty acid $\omega 6 / \omega 3$ than lotic or cultured fish. The results of this study showed that $L$. alexandri is a lean fish (1-2\% of total lipids) and that the environment has a great influence on the fatty acid profile. These results may be a reference for further studies, primarily as a source of information for conservation $L$. alexandri through restocking and the development of commercial projects of aquaculture.

Keywords: Dam, Feeding, Lipids, Pacamã, $\Omega 3$.

Lophiosilurus alexandri é um peixe de água doce, carnívoro, endêmico da bacia do rio São Francisco e encontra-se vulnerável a extinção. Neste estudo, analisamos a composição química (umidade, cinzas, lipídeos e proteína), o perfil de ácidos graxos e qualidade nutricional (índices de aterogênicidade e trombogenicidade, razão entre ácidos graxos hipocolesterolêmicos e hipercolesterolêmicos e $\omega 6 / \omega 3$ ) de L. alexandri em ambientes lóticos (rio), lênticos (hidrelétricas), sob alimentação natural, e em laboratório, com condições controladas e alimentados com dietas comerciais. Os peixes cultivados e capturados em ambientes lênticos apresentaram níveis lipídicos significativamente mais altos (1,5 e 1,9 vezes, respectivamente) do que os peixes cultivados em ambientes lóticos. Os animais cultivados em ambiente lênticos, apresentaram níveis significativamente mais altos de ácido eicosapentaenoico (EPA) (4×) que os animais cultivados em laboratório e ambiente lóticos. Os níveis de ácido docosaexaenoico (DHA) foram os mais altos em peixes lênticos, seguidos pelos peixes lóticos. Os peixes lênticos apresentaram melhor proporção de ácidos graxos $\omega 6 / \omega 3$ que peixes lóticos ou de cativeiro. Os resultados deste estudo mostraram que L. alexandri é um peixe magro (1-2\% do total de lipídios) e que o ambiente tem uma grande influência no perfil de ácidos graxos. Esses resultados podem ser uma referência para novos estudos, principalmente como fonte de informações para sua conservação por meio do repovoamento e desenvolvimento de projetos para sua criação comercial.

Palavras-chave: Alimentação, Barragem, Lipídeos, Pacamã, $\Omega 3$.

${ }^{1}$ Centro de Aquicultura, Universidade Estadual Paulista Júlio de Mesquita Filho. Via de acesso Professor Paulo Donato Castellane, S/N, 14884-900 Jaboticabal, MG, Brazil. (LSSA) santana@fca.unesp.br, Dhttps://orcid.org/0000-0002-1170-7023, (AAI) adriane@zootecnista. com.br, Dhttps://orcid.org/0000-0002-4263-5421

${ }^{2}$ Instituto Brasileiro do Meio Ambiente e dos Recursos Renováveis - IBAMA. Avenida do Contorno, 8.121, Bairro Lourdes, $30110-051$ Belo Horizonte, MG, Brazil. danielcrepaldi@hotmail.com, Dhttps://orcid.org/0000-0002-6691-8602

${ }^{3}$ Laboratório de Aquacultura da Universidade Federal de Minas Gerais (UFMG), Av. Antônio Carlos, 6627, Pampulha, 31270-901 Belo Horizonte, MG, Brazil. (RKL) luzrk@yahoo.com, Dhttps://orcid.org/0000-0002-1021-5772 (corresponding author), (TPB) tuliopb1@ hotmail.com, Dhttps://orcid.org/0000-0002-6143-5417, (LVT) viana.lilian@gmail.com, Dhttps://orcid.org/0000-0001-7878-4085, (EAT) edgarvet@hotmail.com, @ohttps://orcid.org/0000-0002-9549-7499 


\section{Introduction}

The São Francisco River, which is one of the most important Brazilian water resources, is considered the River of National Integration, draining seven states along its 2,863 km (Santos et al., 2014). The basin of the São Francisco River, located in Minas Gerais State, has been subjected to intensive mining and land use for agricultural, urban, and industrial purposes with negative consequences on the chemical and physical integrity of drainage, due to sewage, domestic, and industrial pollution, mining residues, dams, and riparian forest elimination, among others (Langeani et al., 2009).

Adding to the ongoing burdens of intensive agriculture, industrialization and urbanization, climate changes is an additional serious threat to freshwater ecosystems and biodiversity (Liu et al., 2015). Water availability in Brazil depends largely on the climate. The annual cycle of rains and stream flow in the country varies among river basins and on the annual climate changes associated with El Niño and La Niña phenomena (Marengo, 2008). The general effects of climate changes, altered hydrological regimes, and increased ground water temperature could affect the quality of fish (Roland et al., 2012).

Pacamã, Lophiosilurus alexandri Steindachner, 1876 , family Pseudopimelodidae, order Siluriformes is a carnivorous fish, which is endemic of the São Francisco basin (Shibatta, 2003). This fish species presents good fillet quality without bones and is highly valued within the fishing community (Takata et al., 2014). The commercial interest in pacamã is considerable in the region of Submédio São Francisco. Specifically, there is a high demand for consumption and for use as ornamental fish (Campeche et al., 2011).

Pacamã not appear in the latest Red List of International Union for Conservation of Nature (IUCN, 2017), however Fishbase classifies species vulnerability as low to moderate (31 of 100) (Froese, Pauly, 2016). This classification is based on the Fuzzy set theory which aimed to evaluate the extinction vulnerability in: very high, high, moderate and low was scaled arbitrary from 1 to 100 (Cheung et al., 2005).

The Ministry of Environment of Brazil works with National Action Plans for the Conservation of Endangered Species. These guide the priority actions to combat threats that endanger people and their niches, and in the last action plan (Portaria $\mathrm{n}^{\circ} 455$ ) the pacamã is listed as an endangered species (MMA, 2014).

Since 1976, the restocking of reservoirs and rivers with native species has been performed by the electric power company Minas Gerais State (CEMIG). Fry production from the São Francisco River Basin occurs in Fish Culture Station and Hydrobiology Três Marias, in partnership with the Development Company of the Valley of the São Francisco and Parnaíba (CEMIG, 2014). Restocking with native species represents one of the most effective measures for conserving the fish fauna of the São Francisco River and for mitigating the effects caused by the construction of hydroelectric plants. Pacamã is a one of the species that has been used for restocking the São Francisco River (Costa et al., 2015).

To the best of our knowledge, there is no information on the chemical composition and fatty acid profile of pacamã. So, the objective of this study was to evaluate the influence of the environment in the chemical composition, fatty acid profile and nutritional quality of pacamã. The fish samples were collected from three different environments: lotic (rivers), lentic (hydroelectric dams) and laboratory controlled conditions.

\section{Material and Methods}

Pacamã were obtained from São Francisco River and tributaries (lotic fish) $(\mathrm{n}=10)$, the dam of Três Marias (lentic fish) $(\mathrm{n}=10)$, and the aquaculture laboratory (cultured fish) $(\mathrm{n}=10)$, of the Federal University of Minas Gerais (UFMG), Brazil. The representative material of the species used in this study was deposited in the collection of the Coleção Ictiológica at the Museu de Ciências Naturais da PUC Minas (MCNIP 3217). The fish were captured using fishing nets, the captures were realized between April and November 2013. In the laboratory, fish were maintained with ideal conditions (during 12 months the fish were fed with commercial diet to carnivorous fish until apparent satiety twice daily $(08: 00$ and 16:00 h). The average temperature of water was $28{ }^{\circ} \mathrm{C}$, dissolved oxygen above $5 \mathrm{mg} / \mathrm{L}$, in recirculating aquaculture system). This experiment was carried out according to protocols approved by the Comissão de Ética no Uso de Animais (CEUA; Ethics Committee on Animal Use) of UFMG (CEUA Protocol 396/2012). Fish were subsequently euthanized with $285 \mathrm{mg} \mathrm{L}^{-1}$ eugenol overdose (Mattioli et al., 2017), frozen at $-80^{\circ} \mathrm{C}$ and lyophilized for about $36 \mathrm{~h}$. After lyophilization, the samples were transported to the Fish Technology Laboratory of Universidade Estadual Paulista Júlio de Mesquita Filho.

Fulton's condition factor (K). Fish body weight and length were measured to calculate Fulton's condition factor $(\mathrm{K})$ by the following equation.

$$
\mathrm{K}=\left(\mathrm{W} / \mathrm{L}^{3}\right) \times 100
$$

Equation 1. Equation used to calculate Fulton's condition factor $(\mathrm{K})$, where: $\mathrm{W}$ is weight $(\mathrm{g})$ and $\mathrm{L}$ is length $(\mathrm{Cm})$.

Chemical composition and fatty acid profile. The fillets were obtained after removal of the head and skin of the eviscerated fish. Fish cutting started in the dorsal region, lateral to the fin, from the cranial region to the caudal end. The fillets were then lyophilized and crushed for 
analysis. The proximate composition of filet fish $(\mathrm{n}=5$ for treatment) and the commercial diet used at controlled conditions were analysed according to the Association of Official Analytical Chemists (AOAC, 2010): Moisture was determined by oven-drying at $103{ }^{\circ} \mathrm{C}$ to constant weight (AOAC, 938.08). Crude protein was estimated by Kjeldahl method (AOAC, 940.25) with a nitrogento-protein conversion factor of 6.25. Ash was measured following sample incineration in a muffle oven at $550^{\circ} \mathrm{C}$ for $18 \mathrm{~h}$ (AOAC, 923.03). Fatty acids were extracted by the method reported by Folch et al. (1957) and converted into fatty acid methyl esters ( $1 \mathrm{ml}$ of lipids contained 25-50 mg of lipids (Hartman, Lago, 1973). A gas chromatograph (model 3900, Varian Analytical Instruments, Walnut Creek, CA, USA) equipped with a capillary column (Chrompack CP-Sil 88, $100 \mathrm{~m} \times 0.25 \mathrm{~mm} ; 0.20 \mu \mathrm{m}$ ) was used for fatty acid analysis. The injector and detector temperatures were maintained at $270{ }^{\circ} \mathrm{C}$ and $310{ }^{\circ} \mathrm{C}$, respectively. The carrier gas consisted of hydrogen and nitrogen with auxiliary gas, both at $30 \mathrm{ml} / \mathrm{min}$ and with a split ratio of $1 / 75$. The oven temperature program consisted of $140{ }^{\circ} \mathrm{C}$ for $2 \mathrm{~min}$, which was increased to $235^{\circ} \mathrm{C}$ at $2.5^{\circ} \mathrm{C} / \mathrm{min}$ and then maintained at $235^{\circ} \mathrm{C}$ for $10 \mathrm{~min}$. The detector temperature was $310^{\circ} \mathrm{C}$. Fatty acids were identified by comparing their retention times to those of fatty acid standards using FAME standard (Supelco 37 FAME mix). Each fatty acid was quantified by calculating its peak area relative to the total peak area and expressed as fatty acid content relative to total lipid content (\%).

Nutritional quality. Nutritional quality was determined by calculating the aterogenic index (AI), thombogenic index (TI), hypocholesterolemic-to-hypercholesterolemic ratio $(\mathrm{HH})$, and $\omega 6$-to- $\omega 3$ ratio

$$
\begin{gathered}
\mathrm{AI}=(\mathrm{C} 12: 0+\mathrm{C} 14: 0+\mathrm{C} 16: 0) /\left(\sum \mathrm{MUFA}+\sum \mathrm{PUFA}\right) \\
\mathrm{TI}=\left[(\mathrm{C} 14: 0+\mathrm{C} 16: 0+\mathrm{C} 18: 0) /\left(0.5 \times \sum \mathrm{MUFA}\right)+0.5 \times\right. \\
\left.\left.\left.\quad \sum \mathrm{n} 6 \mathrm{PUFA}\right)+3 \times \sum \mathrm{n} 3 \mathrm{PUFA}\right)+(\mathrm{n} 3 / \mathrm{n} 6)\right] \\
\mathrm{HH}=(\mathrm{C} 18: 1 \mathrm{n} 9+\mathrm{C} 18: 2 \mathrm{n} 6+\mathrm{C} 20: 4 \mathrm{n} 6+\mathrm{C} 18: 3 \mathrm{n} 3+ \\
\mathrm{C} 20: 5 \mathrm{n} 3+\mathrm{C} 22: 5 \mathrm{n} 3+\mathrm{C} 22: 6 \mathrm{n} 3) /(\mathrm{C} 14: 0+\mathrm{C} 16: 0)
\end{gathered}
$$

(4) $\omega 6$-to- $\omega 3$ ratio $=\sum$ PUFA $\omega 6 / \sum$ PUFA $\omega 3$

Indexes (1) and (2) were calculated according to the method by Ulbricht, Southgate (1991), and index (3) was determined according to the method by Santos-Silva et al. (2002).

Statistical analysis. The data were analyzed using SAS version 6.12 (SAS Institute Inc., Cary, NC, USA). Significant differences between the means were determined with a Tukey-Kramer test. Differences were considered significant at $P<0.05$.

\section{Results}

The biometrics and proximate composition of cultured, lentic, and lotic fish are presented in Tab. 1. Fish from lentic and lotic environments had higher body weight than cultured fish. The highest and lowest body length was recorded from lotic and cultured fish, respectively. Lotic fish had a significantly lower condition factor $\mathrm{K}$ than cultured or lentic fish. Cultured and lentic fish had significantly higher lipid levels (1.5 and 1.9- fold, respectively) than lotic fish. Cultured fish had significantly lower ash level than lentic and lotic fish. No significant differences were observed in the protein levels of the fish analyzed.

\begin{tabular}{|c|c|c|c|}
\hline & $\begin{array}{c}\text { Lotic } \\
\text { environment }\end{array}$ & $\begin{array}{c}\text { Lentic } \\
\text { environment }\end{array}$ & Aquaculture \\
\hline \multicolumn{4}{|c|}{ Biometrics measurements $(\mathrm{n}=10)$} \\
\hline Total weight (g) & $2274.0 \pm 378.26^{\mathrm{a}}$ & $1560.0 \pm 844.39^{\mathrm{a}}$ & $433.0 \pm 101.3^{\mathrm{b}}$ \\
\hline Length(cm) & $59.61 \pm 3.58^{\mathrm{a}}$ & $46.00 \pm 5.38^{\mathrm{b}}$ & $30.60 \pm 2.70^{\mathrm{c}}$ \\
\hline Condition factor $\mathrm{K}$ & $1.07 \pm 0.07^{\mathrm{b}}$ & $1.49 \pm 0.25^{\mathrm{a}}$ & $1.50 \pm 0.18^{\mathrm{a}}$ \\
\hline \multicolumn{4}{|c|}{ Proximate composition $(\mathrm{g} / 100 \mathrm{~g})(\mathrm{n}=5)$} \\
\hline Moisture & $80.64 \pm 1.23^{\mathrm{a}}$ & $80.25 \pm 1.65^{\mathrm{a}}$ & $79.76 \pm 3.22^{\mathrm{b}}$ \\
\hline Protein & $17.18 \pm 0.69$ & $17.75 \pm 1.26$ & $17.86 \pm 0.37$ \\
\hline Ash & $1.02 \pm 0.04^{\mathrm{ab}}$ & $1.17+0.24^{\mathrm{a}}$ & $0.98 \pm 0.12^{\mathrm{b}}$ \\
\hline Lipid & $1.40 \pm 0.72^{b}$ & $2.10 \pm 0.72^{\mathrm{ab}}$ & $2.66 \pm 0.36^{\mathrm{a}}$ \\
\hline
\end{tabular}

Tab. 1. Biometric measurements and chemical composition of Lophiosilurus alexandri from lotic and lentic environments and aquaculture. Mean \pm standard deviation, different letters in the same row are significantly different $(P<0.05)$.

Cultured fish had significantly $(P<0.05)$ higher myristic Acid (C14), palmitic acid (C16), linoleic Acid (C18:2 n-6), alpha linolenic acid (C18:3 n-3), and total polyunsaturated fatty acids ( $\mathrm{PPUFA}$ ) n6 fatty acid levels than lentic or lotic fish. Lentic pacamãs had significantly higher $(P<0.05)$ eicosapentaenoic acid $(\mathrm{C} 20: 5 \mathrm{n}-3)$ levels $(4 \times)$ than cultured or lotic pacamãs (Tab. 2). Docosahexaenoic acid (C22:6n-3) levels were the highest in lentic fish, followed by lotic fish (Tab. 2).

Tab. 3 presents the chemical and fatty acid composition of feed from the cultured fish. From this table it was observed that linoleic acid (C18:2 n-6), palmitic acid (C16:0) and oleic acid (C18:1 n-9) were present in higher quantity than the others. While the arachidonic acid (C20:4 n-6) percentage in feedstuff was $<1 \%$.

There were no differences in thrombogenecity index (TI), atherogenic index (AI) and ratio between hypocholesterolemic-to-hypercholesterolemic fatty acids (HH) values among the three environment conditions. The $\omega 6$-to- $\omega 3$ PUFA ratio was different among the three habitats. The $\omega 6 / \omega 3$ lowest ratio was observed with lentic fish, whereas the lotic fish showed intermediate values and the cultured higher (Tab. 4). 
Tab. 2. Fatty acid composition ( $\backslash \backslash 100 \mathrm{~g}$ fatty acid) of Lophiosilurus alexandri from lotic and lentic environments and aquaculture. Mean \pm standard deviation $(\mathrm{n}=5)$ followed by different letters to each other $(P<0.05)$. Only the most important fatty acids are listed. $\mathrm{C} 12: 0=$ dodecanoic acid; $\mathrm{C} 14: 0=$ myristic Acid; $\mathrm{C} 15: 0=$ pentadecanoic acid; $\quad$ C16:0=palmitic acid; $\quad$ C17:0 $=$ heptadecanoic acid; $\mathrm{C} 18: 0=$ Stearic acid; $\mathrm{C} 20: 0=$ eicosenoic acid; $\mathrm{C} 21: 0=$ heneicosanoic acid; $C 22: 0=$ docosanoic acid; $\sum$ $\mathrm{SFA}=$ total saturated fatty acids; $\mathrm{C} 16: 1 \mathrm{n}-7=$ palmitoleic acid $=$ Cis 10 -Heptadecenoic acid; C18:1 n-9 trans $=$ acid elaidic; C18:1 n-9= oleic acid; C20:1 n-11= gadoleic acid; $\sum$ MUFA $=$ total de monounsaturated fatty acid; C18:2 n-6=linoleic Acid; C18:3 n-3 trans = trans alpha linolenic acid; $\mathrm{C} 18: 3 \mathrm{n}-3=$ alpha linolenic acid; C20:2 n-6= eicosadienoic acid; C20:4 n-16 trans $=$ trans arachidonic acid; C20:4 $\mathrm{n}-6=$ arachidonic acid; C20:5 n-3= eicosapentaenoic acid; C22:5 n-3 = docosapentaenoic acid; C22:6 n-3 = docosahexaenoic acid; $\sum$ PUFA = total polyunsaturated fatty acids; $\sum$ PUFA n-3 = total polyunsaturated fatty acids n-3 e $\sum$ PUFA n-3= total polyunsaturated fatty acids $n-6$.

\begin{tabular}{|c|c|c|c|}
\hline Fatty acid & $\begin{array}{c}\text { Lotic } \\
\text { environment }\end{array}$ & $\begin{array}{c}\text { Lentic } \\
\text { environment }\end{array}$ & Aquaculture \\
\hline $\mathrm{C} 12: 0$ & $0.04 \pm 0.06$ & $0.04 \pm 0.06$ & $0.04 \pm 0.06$ \\
\hline $\mathrm{C} 14: 0$ & $2.17 \pm 0.53^{\mathrm{a}}$ & $2.23 \pm 0.57^{\mathrm{a}}$ & $2.28 \pm 0.18^{b}$ \\
\hline C15:0 & $0.66 \pm 0.31$ & $1.09 \pm 1.01$ & $0.25 \pm 0.03$ \\
\hline $\mathrm{C} 16: 0$ & $26.03 \pm 0.65^{b}$ & $25.68 \pm 1.57^{b}$ & $28.42 \pm 0.63^{\mathrm{a}}$ \\
\hline $\mathrm{C} 17: 0$ & $1.45 \pm 0.36^{\mathrm{a}}$ & $1.03 \pm 0.17^{\mathrm{b}}$ & $0.46 \pm 0.07^{c}$ \\
\hline C18:0 & $9.16 \pm 0.37^{\mathrm{a}}$ & $7.22 \pm 0.59^{b}$ & $6.82 \pm 0.15^{\mathrm{b}}$ \\
\hline C20:0 & $0.19 \pm 0.15$ & $0.27 \pm 0.07$ & $0.35 \pm 0.02$ \\
\hline $\mathrm{C} 21: 0$ & - & $0.05 \pm 0.05$ & - \\
\hline $\mathrm{C} 22: 0$ & $0.21 \pm 0.12$ & $0.13 \pm 0.13$ & $0.21 \pm 0.13$ \\
\hline$\sum \mathrm{SFA}$ & $40.00 \pm 1.64^{\mathrm{a}}$ & $37.74 \pm 1.18^{b}$ & $38.97 \pm 0.89^{\mathrm{a}}$ \\
\hline C16:1n-7 & $4.39 \pm 1.08^{b}$ & $9.01 \pm 4.24^{\mathrm{a}}$ & $3.93 \pm 0.49^{b}$ \\
\hline $\mathrm{C} 17: 1$ & $0.57+0.14^{\mathrm{a}}$ & $0.49 \pm 0.11^{\mathrm{ab}}$ & $0.34 \pm 0.05^{\mathrm{b}}$ \\
\hline C18:1 n-9 trans & $0.33 \pm 0.22$ & $0.27 \pm 0.16$ & $0.38 \pm 0.21$ \\
\hline C18:1 n-9 & $23.16 \pm 1.30^{\mathrm{b}}$ & $18.25 \pm 2.46^{\mathrm{c}}$ & $26.37 \pm 0.63^{\mathrm{a}}$ \\
\hline C20:1 n-11 & $3.65 \pm 0.95^{\mathrm{a}}$ & $0.94 \pm 0.42^{\mathrm{b}}$ & $1.11 \pm 0.17^{\mathrm{b}}$ \\
\hline$\sum$ MUFA & $32.51 \pm 2.47$ & $29.03 \pm 3.06$ & $32.28 \pm 0.61$ \\
\hline$C 18: 2 n-6$ & $5.84 \pm 0.80^{\mathrm{b}}$ & $4.79 \pm 0.32^{\mathrm{b}}$ & $14.25 \pm 0.93^{\mathrm{a}}$ \\
\hline C18:3 n-3 trans & $0.13 \pm 0.17^{\mathrm{b}}$ & $0.20 \pm 0.05^{\mathrm{b}}$ & $0.53 \pm 0.05^{\mathrm{a}}$ \\
\hline $\mathrm{C} 18: 3 \mathrm{n}-3$ & $1.12 \pm 0.37^{\mathrm{b}}$ & $2.13 \pm 0.63^{\mathrm{a}}$ & $0.32 \pm 0.39^{\mathrm{b}}$ \\
\hline$C 20: 2 n-6$ & $0.85 \pm 0.11^{\mathrm{a}}$ & $0.33 \pm 0.04^{c}$ & $0.48 \pm 0.04^{b}$ \\
\hline C20:4 n-6 & $3.14 \pm 1.32^{2 \mathrm{~b}}$ & $3.83 \pm 1.87^{\mathrm{a}}$ & $1.35 \pm 0.19^{b}$ \\
\hline $\mathrm{C} 20: 5 \mathrm{n}-3$ & $0.99 \pm 0.12^{\mathrm{b}}$ & $3.74 \pm 1.25^{\mathrm{a}}$ & $0.96 \pm 0.06^{\mathrm{b}}$ \\
\hline $\mathrm{C} 22: 5 \mathrm{n}-3$ & $1.52 \pm 0.41^{\mathrm{b}}$ & $2.20 \pm 0.50^{\mathrm{a}}$ & $0.87 \pm 0.05^{\mathrm{c}}$ \\
\hline $\mathrm{C} 22: 6 \mathrm{n}-3$ & $4.22 \pm 2.14^{b}$ & $6.52 \pm 2.85^{\mathrm{a}}$ & $3.60 \pm 0.23^{\mathrm{c}}$ \\
\hline$\sum$ PUFA & $18.74 \pm 3.45^{\circ}$ & $25.53 \pm 5.87^{\mathrm{a}}$ & $23.17 \pm 3.50^{\mathrm{b}}$ \\
\hline ¿ PUFA n-3 (g/100g flesh) & $0.096 \pm 0.144^{b}$ & $0.278 \pm 0.186^{\mathrm{a}}$ & $0.142 \pm 0.448^{b}$ \\
\hline ¿ PUFA n-6 (g/100g flesh) & $0.144 \pm 0.059^{\mathrm{b}}$ & $0.186 \pm 0.021^{\mathrm{b}}$ & $0.448 \pm 0.048^{\mathrm{a}}$ \\
\hline
\end{tabular}

Tab. 3. Chemical and fatty acid composition of feed. Mean \pm standard deviation. $\mathrm{C} 16: 0=$ palmitic acid; $\mathrm{C} 16: 1=$ palmitoleic acid; $\mathrm{C} 18: 1 \mathrm{n}-9=$ oleic acid; $\mathrm{C} 20: 1 \mathrm{n} 11=$ eicosenoic acid; C18:2 n-6= linoleic Acid; C18:3 n-3= alpha linolenic acid; $\mathrm{C} 20: 2 \mathrm{n}-6=$ eicosadienoic acid; $\mathrm{C} 20: 4 \mathrm{n}-6=$ arachidonic acid; $\mathrm{C} 20: 5 \mathrm{n}-3=$ eicosapentaenoic acid; $\mathrm{C} 22: 5 \mathrm{n}-3=$ docosapentaenoic acid; $\mathrm{C} 22: 6 \mathrm{n}-3=$ docosahexaenoic acid.

\begin{tabular}{lc}
\hline Chemical composition & $8.88 \pm 0.26$ \\
\hline Moisture $(\mathrm{g} / 100 \mathrm{~g})$ & $36.72 \pm 1.48$ \\
Protein $(\mathrm{g} / 100 \mathrm{~g})$ & $8.82 \pm 0.11$ \\
Ash $(\mathrm{g} / 100 \mathrm{~g})$ & $6.99 \pm 0.33$ \\
Lipids $(\mathrm{g} / 100 \mathrm{~g})$ & \\
\hdashline Fatty acid & $21.20 \pm 0.34$ \\
$\mathrm{C} 16: 0$ & $2.89 \pm 0.07$ \\
$\mathrm{C} 16: 1$ & $28.25 \pm 0.64$ \\
$\mathrm{C} 18: 1 \mathrm{n}-9$ & $2.09 \pm 0.15$ \\
$\mathrm{C} 20: 1 \mathrm{n}-11$ & $24.10 \pm 0.67$ \\
$\mathrm{C} 18: 2 \mathrm{n}-6$ & $0.60 \pm 0.03$ \\
$\mathrm{C} 18: 3 \mathrm{n}-3$ & $0.19 \pm 0.03$ \\
$\mathrm{C} 20: 2 \mathrm{n}-6$ & $0.54 \pm 0.31$ \\
$\mathrm{C} 20: 4 \mathrm{n}-6$ & $1.30 \pm 0.03$ \\
$\mathrm{C} 20: 5 \mathrm{n}-3$ & $0.50 \pm 0.03$ \\
C22:5 n-3 & $1.80 \pm 0.15$ \\
C22:6 n-3 &
\end{tabular}

Tab. 4. Nutritional quality assessment of Lophiosilurus alexandri from lotic and lentic environments and aquaculture. Mean \pm standard deviation $(\mathrm{n}=5)$ followed by different letters to each other $(P<0.05)$. $\mathrm{AI}=$ Atherogenic index, $\mathrm{TI}=$ Thrombogenecity index, $\mathrm{HH}=$ ratio between hypocholesterolemic and hypercholesterolemic fatty acids and $\omega 6 / \omega 3=$ ratio.

\begin{tabular}{lccc}
\hline & Lotic environment & Lentic environment & Aquaculture \\
\hline $\mathrm{AI}$ & $0.71 \pm 0.10^{\mathrm{a}}$ & $0.65 \pm 0.08^{\mathrm{a}}$ & $0.67 \pm 0.03^{\mathrm{a}}$ \\
$\mathrm{TI}$ & $1.65 \pm 0.11^{\mathrm{a}}$ & $1.48 \pm 0.11^{\mathrm{a}}$ & $1.55 \pm 0.10^{\mathrm{a}}$ \\
$\mathrm{HH}$ & $1.42 \pm 0.19^{\mathrm{a}}$ & $1.50 \pm 0.31^{\mathrm{a}}$ & $1.56 \pm 0.09^{\mathrm{a}}$ \\
$\omega 6 / \omega 3$ & $1.56 \pm 0.18^{\mathrm{b}}$ & $0.67 \pm 0.04^{\mathrm{c}}$ & $3.19 \pm 0.53^{\mathrm{a}}$ \\
\hline
\end{tabular}

\section{Discussion}

The difference of body weight and body length is difficult to compare because the age of animals captured in natural conditions is unknown. The nutritional composition of fish may vary depending on their stage of development (Costa et al., 2018), feeding (Li et al., 2014) and species (Mohanty et al., 2019). Fish containing levels of protein greater than $15 \%$ are considered a high nutritional value food (Coutinho et al., 2019; Memon et al., 2011). In addition, fish are commonly classified into groups according to their total lipid content: high-fat ( $>$ $8 \%$ ), medium-fat ( $4 \%$ to $8 \%$ ), low-fat ( $2 \%$ to $4 \%$ ) and lean $(<2 \%)$ (Haard, 1992). Due to the characteristics found in the present study, pacamã proved to be a food with high nutritional value. 
The condition factor $\mathrm{K}$ reflects the physical and biological fluctuations in feeding conditions, parasitic infections, and physiological factors (Le Cren, 1951). Morphometric condition indicators represent the simplest indicators of energy storage in fish species (Lloret et al., 2014). The $K$ index is based on the assumption that within a cohort, individuals with high $\mathrm{K}$ values contain more energy reserves (fat and protein) than those with low $\mathrm{K}$ values (Caldarone et al., 2012). These results may be attributed to higher lipid reserves in fish of lentic and aquaculture habitats.

LA values, which were three times higher in cultured fish, explain the high $\sum$ PUFA n6 values. The high levels of C18:2 n-6 in cultured fish have been attributed to the presence of plant-based C18:2 $\mathrm{n} 6$ in the feed (Grigorakis, 2007). The main ingredient of the feed was soybean meal which contained high C18:2 n-6, levels.

The fatty acid trophic marker is based on the observation that the primary producer lays down certain fatty acid patterns that may be conservatively transferred (Dalsgaard et al., 2003). Cyanobacteria and diatoms contain C16:1 n-7 (Mortillaro et al., 2011) and EPA (C20: 5 n-3) (Lau et al., 2009). These two fatty acids are biomarkers of cyanobacteria and diatoms in freshwater habitats (Lau et al., 2009). Compared to cultured and lotic fish, lentic fish had significantly higher levels of these fatty acids, suggesting that in this environment there are higher amounts of cyanobacteria and diatoms, food source for of smaller fish and crustaceans that will be consumed by pacamã. Certain herbivorous copepods produce considerable amounts of C20:1 n11 from the desaturation of C20:00 (Dalsgaard et al., 2003; Saito, Murata, 1998), which may explain the higher amount of this fatty acid in lotic fish.

Ulbricht, Southgate (1991) developed AI and TI, which are based on the fatty acid profile of the animal and its contribution to either the prevention or promotion of coronary heart disease in humans (Valfré et al., 2003). AI represents the ability to reduce blood lipid content, and TI represents the ability to inhibit platelet activity in humans. Low AI and TI values are indicative of a cardioprotective effect (Grigorakis et al., 2011). In this study, there were no differences in TI or AI values among lentic, lotic, and aquaculture habitats. HH is directly related to cholesterol metabolism. High $\mathrm{HH}$ values are considered to be beneficial for human health (Ramos-Filho et al., 2010). In this study, there were no differences in $\mathrm{HH}$ values among the three habitats. Similar results were reported in other Brazilian freshwater fish (Ramos-Filho et al., 2010). The $\omega 6$-to- $\omega 3$ PUFA ratio was different among the three habitats. The lowest ratio was observed with lentic fish.

It has been reported that cultured fish have lower C20:4 n-6 levels than their wild counterparts (Rodríguez-Barreto et al., 2012), possibly due to substantially higher C20:4 n-6 levels in the natural feed (Jainkowska et al., 2010). In this study, the C20:4 n-6 percentage is in agreement with the findings reported by Fasolato et al. (2010).
Our study findings revealed that the lipid levels of fish in aquaculture environments were higher than those of lotic, which suggests that habitat has a significant impact on lipid synthesis in fish (Deka et al., 2012).

Fish with high C20:5 n-3 (EPA) and C22:6 n-3 (DHA) levels and low $\omega 6$-to- $\omega 3$ ratios constitute a fundamental part of a healthy human diet (Turchini et al., 2009). The European Food Safety Authority recommends the daily consumption of $250 \mathrm{mg}$ C20:5 n-3 (EPA) + $250 \mathrm{mg} \mathrm{C} 22: 6$ n-3 (DHA) (EFSA, 2010). Lentic, cultured, and lotic pacamã (100 g) provide $74 \%, 44 \%$, and $28 \%$, respectively, of the recommended daily C20:5 n-3 (EPA) + C22:6 n-3 (DHA).

A $\omega 6$-to- $\omega 3$ PUFA ratio of $3: 1$ to $4: 1$ might prevent several diseases characteristic of the Western diet (ANSES, 2011). A $\omega 6$-to- $\omega 3$ PUFA ratio of $1: 1$ to $2: 1$ appears to be consistent with studies on evolutionary aspects of diet, neurodevelopment, and genetics (Simopoulos, 2010). In this study, the $\omega 6$-to- $\omega 3$ PUFA ratio were lower than those considered to be harmful to human health. Additionally, lentic and lotic fish had ideal ratios.

ARA is the main precursor of eicosanoids C20:5 n-3 (EPA) competitively interferes with ARA in the production of these hormone-like compounds, and C20:5 n-3 (EPA) derivatives are less biologically active than ARA derivatives (Rodríguez-Barreto et al., 2012). The high levels of C20:4 $\mathrm{n}-6$ in lentic or lotic fish may function as suggested by Ogata et al. (2004); C20:4 n-6 is nutritionally more important in tropical species that in cold/temperate water species.

The fish used in this study were collected in 2013; however, some considerations are necessary because of climate changes in 2014 and 2015 in Brazil. From September 2014 to February 2015, the total rainfall over a large region of South Eastern Brazil was considered to be one of the lowest ever recorded (Liberto, 2015). Pacamã is an endemic, endangered fish of São Francisco River. The evolutionary history of tropical riverine ecosystems is complex and has contributed to high levels of endemism, because dams and other hydrological modifications can result in the loss of endemic species (Pringle et al., 2000). In lentic systems, eutrophication may be exacerbated or offset, and stratification will likely become more pronounced and stronger as a result of climate changes (Roland et al., 2012).

In summary, the results of this study showed that pacamã is a lean fish ( $1-2 \%$ of total lipids) and that the environment has a great influence on the fatty acid profile. Pacamã from the lentic environment has a high C22:6 n-3 (DHA) content, so it becomes more nutritionally suitable. Our study findings can be used as a preliminary data collection for further elaborated study to evaluate how climate changes in Brazil affect lipid metabolism of pacamã in different environments. Similar studies will be carried out from 2020 to 2021 to check the the chemical characteristics of the species in lentic and lotic environment after water stress, as well as the effects of prolonged drought in the nutritional characteristics of pacamã. 


\section{Acknowledgements}

This study was supported by Project 270/11 from CAPES (Brazil) and FCT (Portugal), FAPESP Project 2013/10477-9 (Brazil) and FAPEMIG (Brazil). LUZ, R.K. received a research grant from the Conselho Nacional de Desenvolvimento Científico e Tecnológico (CNPq No. 308547/2018-7).

\section{References}

Agence Nationale de Sécurité Sanitaire Alimentation et Travail. Actualisation des apports nutritionnels conseillés pour les acides gras. Rapport d'expertise collective. Maisons-Alfort Cedex: ANSES; 2011. Available from: https://www.anses.fr/fr/ system/files/NUT2006sa0359Ra.pdf

Association of Official Agricultural Chemists (AOAC). Official methods of analysis of analysis of the association of official analytical chemists. Arlington: AOAC International; 2010.

Ministério do Meio Ambiente (MMA). Portaria MMA n ${ }^{\circ} 445$, de 17 de janeiro de 2014. Lista nacional oficial de espécies da fauna ameaçadas de extinção: peixes e invertebrados aquáticos [Internet]. Brazil; 2014. Available from: http://bit.ly/2VFiVRw

Caldarone EM, MacLean SA, Sharack B. Evaluation of bioelectrical impedance analysis and Fultons'condition factor as nonlethal techniques for estimating short-term responses in postsmolt Atlantic salmon (Salmo salar) to food availability. Fish Bull. 2012; 110(2):257-70. Available from: https://spo.nmfs.noaa. gov/sites/default/files/pdf-content/2012/1102/caldarone.pdf

Campeche DFB, Balzana L, Figueiredo RCR, Barbalho MRS, Reis FJS, Melo JFB. Peixes nativos do rio São Francisco adaptados para cultivo. Petrolina: Embrapa; 2011. Available from: https://www.infoteca.cnptia.embrapa.br/infoteca/bitstream/ doc/916922/1/SDC244.pdf

Companhia Energética de Minas Gerais (CEMIG). Piscicultura e peixamentos [Internet]. Belo Horizonte: CEMIG; 2014. Available from: http://www.cemig.com.br/pt-br/A_Cemig_e_o Futuro/sustentabilidade/nossos_programas/ambientais/peixe_ vivo/programas_de_conservacao/Paginas/psicicultura_e_ peixamentos.aspx

Cheung WWL, Pitcher TJ, Pauly D. A fuzzy logic expert system to estimate intrinsic extinction vulnerabilities of marine fishes to fishing. Biol Conserv. 2005; 124(1):97-111. https://doi. org/10.1016/j.biocon.2005.01.017

Costa DC, Takata R, Silva WS, Bessonart M, Gadea JL, Magnone L, Luz RK. Description of amino acid and fatty acid content during initial development of Lophiosilurus alexandri (Siluriformes: Pseudopimelodidae), a carnivorous freshwater catfish. Neotrop Ichthyol. 2018; 16(2):e180014. http://dx.doi.org/10.1590/1982-0224-20180014

Costa DC, Silva WS, Melillo-Filho R, Miranda-Filho KC, Santos JCE, Luz RK. Capture, adaptation and artificial control of reproduction of Lophiosilurus alexandri: A carnivorous freshwater species. Anim Reprod Sci. 2015; 159(1):148-54. https://doi.org/10.1016/j.anireprosci.2015.06.009

Coutinho NM, Canto ACVCS, Mársico ET, Silva FA, Keller LAM, Conte-Junior CA, Monteiro MLG. Fatty acid composition and influence of temperature on the lipid stability of Arapaima gigas meat. Braz J Food Technol. 2019; 22(1):e2018132. https://doi.org/10.1590/1981-6723.13218
Dalsgaard J, John MS, Kattner G, Müller-Navarra D, Hagen W. Fatty acid trophic marker in the pelagic marine environment. Adv Mar Biol. 2003; 46(1):225-340. https://doi.org/10.1016/ S0065-2881(03)46005-7

Deka BK, Mahanta R, Goswami UC. Impact of seasonal and habitat variation on composition of total lipid content in muscle and liver of Labeo gonius (Ham). IJSRP. 2012; 2(6):1-4. Available from: http://www.ijsrp.org/research_paper_jun2012/ ijsrp-June-2012-53.pdf

European Food Safety Authority Panel on Dietetic Products, Nutrition, and Allergies (EFSA). Scientific opinion on dietary reference values for fats, including saturated fatty acids, polyunsaturated fatty acids, monounsaturated fatty acids, trans fatty acids, and cholesterol. ESFA J. 2010; 8(3):1461. https:// doi.org/10.2903/j.efsa.2010.1461

Fasolato L, Novelli E, Salmaso L, Corain L, Camin F, Perini M, Antonetti P, Balzan S. Application of nonparametric multivariate analyses to the authentication of wild and farmed European sea bass (Dicentrarchus labrax): Results of a survey on fish sampled in the retail trade. J Agric Food Chem. 2010; 58(20):10979-88. https://doi.org/10.1021/jf1015126

Folch J, Lees M, Stanley GHS. A simple method for the isolation and purification of total lipids from animal tissues. J Biol Chem. 1957; 226(1):497-509. Available from: http://www.jbc. org/content/226/1/497.long

Froese R, Pauly D. Fish Base World Wide Web electronic publication [Internet]; 2016. Available from: https://www. fishbase.org

Grigorakis K, Fountoulaki E, Vasilaki A, Mittakos I, Nathanailides C. Lipid quality and filleting yield of rare meagre (Argyrosomous regius). Int J Food Sci Technol. 2011; 46(4):711-16. https:// doi.org/10.1111/j.1365-2621.2010.02537.x

Grigorakis K. Compositional and organoleptic quality of farmed and wild gilthead sea bream (Sparus aurata) and sea bass (Dicentrarchus labrax) and factors affecting it: A review. Aquaculture. 2007; 272(1-4):55-75. https://doi.org/10.1016/j. aquaculture.2007.04.062

Haard NF. Control of chemical composition and food quality attributes of cultured fish. Food Res Int. 1992; 25(4):289-307. http://dx.doi.org/10.1016/0963-9969(92)90126-P

Hartman L, Lago RC. Rapid preparation of fatty acid methyl esters from lipids. Lab Pract. 1973; 22(6):475-76.

International Union for Conservation of Nature (IUCN). Standards and petitions subcommittee. Guidelines for using the IUCN Red List categories and criteria. Version 13 [Internet]. Gland; 2017. Available from: http://cmsdocs.s3.amazonaws.com/ RedListGuidelines.pdf

Jainkowska B, Zakeś Z, Źmijewski T, Szczepkowski M. Fatty acid profile of muscles, liver and mesenteric fat in wild and reared perch (Perca fluviatilis L). Food Chem. 2010; 118(3):764-68. https://doi.org/10.1016/j.foodchem.2009.05.055

Langeani F, Buckup PA, Malabarba LR, Rapp Py-Daniel LH, Lucena CAS, Rosa RS et al. Peixes de Água Doce. In: Rocha RM, Boeger WAP, editors. Estado da arte e perspectivas para a zoologia no Brasil. Curitiba: Sociedade Brasileira de Zoologia; 2009. p.211-30.

Lau DCP, Leung KMY, Dudgeon D. Are autochthonous food more important than allochthonous resources to benthic consumers in tropical headwater streams? J North Am Benthol Soc. 2009; 28(2):426-39. https://doi.org/10.1899/07-079.1 
Le Cren ED. The length-weight relationship and seasonal cycle in gonad weight and condition in the perch (Perca fluviatalis). J Anim Ecol. 1951;20(2):201-19. http://dx.doi.org/10.2307/1540

Li X, Zhu X, Han D, Yang Y, Jin J, Xie S. Carbohydrate utilization by herbivorous and omnivorous freshwater fish species: a comparative study on gibel carp (Carassius auratus gibelio. var CAS III) and grass carp (Ctenopharyngodon idellus). Aquac Res. 2014; 47(1):128-39. https://doi.org/10.1111/are.12476

Liberto TD. It's supposed to be the rainy season in Brazil, so where has all the water gone [Internet]. NOAA Climate.gov; 2015. Available from: http:/www.climate.gov/news-features/eventtracker/its-supposed-be-rainy-season-in-Brazil-so-where-hasall-water-gone

Liu J, Kattel G, Arp HPH, Yang H. Towards threshold-based management of freshwater ecosystems in the context of climate change. Ecol Modell. 2015; 318(1):265-74. https://doi. org/10.1016/j.ecolmodel.2014.09.010

Lloret J, Shulman G, Love RM. Description of condition indicators. In: Lloret J, Shulman G, Love RM, editors. Condition and health indicators of exploited marine fishes. Hoboken: John Wiley; 2014. p.1-16.

Marengo JA. Water and climate change. Estud Av. 2008; 22(63):8396. http://dx.doi.org/10.1590/S0103-40142008000200006

Mattioli CC, Takata R, Leme FOPL, Costa DC, Filho RM, Silva WS, Luz RK. The effects of acute and chronic exposure to water salinity on juveniles of the carnivorous freshwater catfish Lophiosilurus alexandri. Aquaculture. 2017; 481(1):25566. https://doi.org/10.1016/j.aquaculture.2017.08.016

Memon NN, Talpur FN, Bhanger MI, Balouch A. Changes in fatty acid composition in muscle of three farmed carp fish species (Labeo rohita, Cirrhinus mrigala, Catla catla) raised under the same conditions. Food Chem. 2011; 126(2):405-10. http:// dx.doi.org/10.1016/j.foodchem.2010.10.107

Mohanty BP, Mahanty A, Ganguly S, Mitra T, Karunakaran D, Anandan R. Nutritional composition of food fishes and their importance in providing food and nutritional security. Food Chem. 2019; 293(1):561-70. https://doi.org/10.1016/j. foodchem.2017.11.039

Mortillaro JM, Abril G, Moreira-Turq P, Sobrinho RJ, Perez M, Meziane T. Fatty acid ans stable isotope $\left(\mathrm{d}^{13} \mathrm{C}, \mathrm{d}^{15} \mathrm{~N}\right)$ signatures of particulate organic matter in the lower Amazon River: Seasonal contrasts and connectivity between floodplain lakes and mainstream. Org Geochem. 2011; 42(10):1159-68. https:// doi.org/10.1016/j.orggeochem.2011.08.011

Ogata HY, Emala AC, Garibay ES, Furuita H. Fatty acid composition of five candidate aquaculture species in Central Philippines. Aquaculture. 2004; 236(1-4):361-75. https://doi. org/10.1016/j.aquaculture.2003.10.015

Pringle CM, Freeman MC, Freeman BJ. Regional effects of hydrologic alterations on riverine macrobiota in the new world: Tropical-temperate comparison. BioScience. 2000; 50(9):80723. https://doi.org/10.1641/0006-3568(2000)050[0807:REOH $\mathrm{AO}] 2.0 . \mathrm{CO} ; 2$

Ramos-Filho MM, Ramos MIL, Hiane PA, Souza EMT. Nutritional value of seven freshwater fish species from the Brazilian Pantanal. J Am Oil Chem Soc. 2010; 87(12):1461-67. https:// doi.org/10.1007/s11746-010-1639-1
Rodríguez-Barreto D, Jerez S, Cejas JR, Martin MV, Acosta NG, Bolaños A, Lorenzo A. Comparative study of lipid and fatty acid composition in diferente tissues of wild and culture female broodstock of greater amberjack (Seriola dumerili). Aquaculture. 2012; 360-361(1):1-9. https://doi.org/10.1016/j. aquaculture.2012.07.013

Roland F, Huszar VLM, Farjalla VF, Enrich-Prast A, Amado AM, Ometto JPBH. Climate change in Brazil: perspectives on the biogeochemistry of inland water. Braz J Biol. 2012; 72(3):70922. http://dx.doi.org/10.1590/S1519-69842012000400009

Saito H, Murata M. Origin of the monoene fats in the lipid of midwater fishes: relationship between the lipids of mycophids and those of their prey. Mar Ecol Prog Ser. 1998; 168(1):2133. https://doi.org/10.3354/meps168021

Santos LCM, Matos HR, Schaeffer-Novelli Y, Cunha-Lignon M, Bittencourt MD, Koedam N, Dahdouh-Guebas F. Anthropogenic activies on mangrove areas (São Francisco river estuary, Brazil, Northeast): A GIS-based analysis of CBERS and SPOT images to aid in local management. Ocean Coast Manag. 2014; 89(1):39-50. https://doi.org/10.1016/j. ocecoaman.2013.12.010

Santos-Silva J, Bessa RJB, Santos-Silva F. Effect of genotype, feeding system and slaughter weight on the quality of light lambs: II. Fatty acid composition of meat. Livest Prod Sci. 2002; 77(2-3):187-94. https://doi.org/10.1016/S03016226(02)00059-3

Shibatta OA. Family Pseudopimelodidae. In: Reis RE, Kullander $\mathrm{SO}$, Ferraris CJ, editors. Check list of the freshwater fisher of South and Central America. Porto Alegre: EDIPUCRS; 2003. p.401-05.

Simopoulos AP. The omega-6/omega-3 fatty acid ratio: health implications. OCL. 2010; 17(5):267-75. https://doi.org/10.1051/ ocl.2010.0325

Takata R, Silva WS, Costa DC, Melillo-Filho R, Luz RK. Effect of water temperature and prey concentrations on initial development of Lophiosilurus alexandri Steindachner, 1876 (Siluriformes: Pseudopimelodidae), a freshwater fish. Neotrop Ichthyol. 2014; 12(4):853-59. https://doi.org/10.1590/19820224-20140063

Turchini GM, Torstensen BE, Ng WK. Fish oil replacement in finfish nutrition. Rev Aquac. 2009; 1(1):10-57. https://doi. org/10.1111/j.1753-5131.2008.01001.x

Ulbricht TLV, Southgate DAT. Coronary heart disease: seven dietary factors. Lancet. 1991; 338(8773):985-92. https://doi. org/10.1016/0140-6736(91)91846-M

Valfré F, Caprino F, Turchini GM. The health benefit of seafood. Vet Res Commun. 2003; 27(1):507-12. https://doi.org/10.1023/ B:VERC.0000014208.47984.8c 